MARIJA MOLAN, Ph.D.

E-mail: marija@molan.ws

University Clinical Centre Ljubljana

Institute for Occupational Health

Poljanski nasip 58, SI-1000 Ljubljana, Slovenia

GREGOR MOLAN, M.Sc.

E-mail: gregor.molan@comtrade.com

Comtrade d.o.o.

Litijska cesta 51, SI-1000 Ljubljana, Slovenia
Human-Transport Interaction

Preliminary Communication

Accepted: Aug. 24, 2010

Approved: May 17, 2011

\title{
BFS HUMAN BEHAVIOUR MODEL FOR TRAFFIC SAFETY
}

\begin{abstract}
The Butterfly Flower Shower (BFS) Human Behaviour Model describes human behaviour in each demanding, possible accidental situation. The BFS human behaviour model is presented for a traffic situation. The key elements (perception, cognition, reaction) of the human behaviour are identified. Also possible limitations and errors in all elements of human behaviour are presented. The model is presented as the butterfly on the flower under the shower of interventions. The flower is environment describing traffic infrastructure composed of the environment, technology and organization. The body of the butterfly is human cognition with personality and motivation. The left wing of the butterfly is the driver's perception. The right wing of the butterfly is the driver's reaction. The butterfly presents the driver, the flower presents the road - the traffic infrastructure and the shower presents the shower of humanization interventions into the traffic infrastructure and into the driver. The drops from the shower are related to identified limitations in the traffic infrastructure and to the driver. They are focused on the improvements of perception, cognition and reaction abilities of the driver also with investments into the traffic infrastructure.
\end{abstract}

\section{KEY WORDS}

BFS Human Behaviour Model, perception, cognition, reaction, behaviour pattern, traffic infrastructure, traffic, driver, model of behaviour, humanization interventions

\section{INTRODUCTION}

According to the results of root cause analysis majority of all incidents and accidents are caused by human error [1]. About $80 \%$ of all incidents are initiated by inadequate human behaviour.

These are the results of root cause analyses implemented in industry. In the traffic situation, the role of a driver driving a car, the role of a designer of the traffic infrastructure or the role of a constructor are no less important than in the industrial situation. In the focus of this paper is the driver driving a vehicle. A driver in traffic can be compared to a worker at a workplace. Approaches from industrial researches should be the basis for researches of human behaviour in the traffic situation [5].

Human behaviour is external manifestation of internal process in the individual. Those external manifestations are shaped with impacts of environment on the human being. According to the AH model [2] external factors affecting the individual are the following:

- Environmental factors: surrounding of the individual composed of light, noise, temperature and humidity of the environment, weather, and special situation - a tunnel.

- These external factors influence the individual in the form of stimuli.

- Technological factors: technology available to the individual in a situation.

- These are the infrastructure of the road or tunnel and the technology of the car driven by an individual.

- Organizational factors: rules and procedures obligatory in the particular environment.

- These are speed limits, light rules, right- and left-hand traffic.

- Personality factors: basic abilities and health status of the individual driving the vehicle.

- These are human factors in the traffic situation. These external factors (environment, technology, and organization) influence the human behaviour in the form of stimuli. Particular external manifestations of the internal processes in the individual are integrated in models describing human behaviour in the real traffic situation. Human behaviour is shaped with the influence of internal factors of the driver and external factors. Internal factors are according to the AH-Model personality factors. Inside the group of personality factors, motivation [6], and stress [7] are important. Due 
to the huge impact of those factors on human behaviour they are not described in this paper. Also, impacts of psychoactive substances (alcohol, illegal and prescribed drugs) on driver's fitness for duty are not particularly described [8]. Those impacts need special description. External manifestations of driver's behaviour are mostly the only applicable elements with potential ability of incorporation in the model presenting driver's behaviour in the traffic situation.

Human behaviour determines the level of traffic safety. The level of traffic safety is the most important aspect of traffic for all traffic cases. All interventions to the traffic have as the main purpose: improvement of traffic safety [20].

\subsection{Driver-traffic infrastructure relation}

There are different models describing the role of a driver in the process of traffic [9]. According to the decision-making model there is an evident relation between the quality of the performed behavioural pattern and the probability of inadequate decision made [10]. Faster reactions may often be related to making wrong decisions. These reactions are often late, due to the underestimation of the situation, and perceived information. To insure adequate in-time reaction intime adequate perception of information is necessary. According to the results of tunnel accidents analyses it is evident that the individuals often underestimate the situation [21]. They simply do not believe that something serious is going on. They believe that nothing serious can happen in short time, during the time when they are in the situation. Maybe the information means something for the future, but not for them in the near future. When they realize that the information is crucial for them, it is often late, or too late.

\subsection{Butterfly Model}

On the basis of accident root cause analysis, roots of an accident, an accident and consequences of the accident are presented in the form of a butterfly [3]. The same form of presentation should be used also for the presentation of human behaviour [4]. The proposed butterfly model is based on Stimulus-OrganismReaction model [11] with a special concern on stimuli elements, behaviour patterns basis in the organism, and reaction as external manifestation.

According to the Butterfly Model the whole situation is presented with the butterfly [4]. In the body of the animal there are all different behaviour patterns of humans involved in the accident. Behavioural patterns are hidden inside the butterfly body. These patterns are defined as the root causes of the accident or event, but they are not analysed. Only external manifestations are taken into account.
In all these models, there are no analyses of internal manifestations. These internal manifestations are facts incorporated in particular root cause analyses. The behavioural patterns have to be identified and built into the model. It depends on the model's idea which data of behavioural patterns will be used. So much information has to be used that the applicable presentation of the event's occurrence will be possible. Adequate and reliable information built in the model describe the accident in a way that prevents occurrence of the same accident or the similar one after the implementation of protective measures. These protective measures are implemented according to the result of implementing the risk assessment model.

\section{HYPOTHESIS}

It is possible to develop a conceptual model describing the key elements of human behaviour presented in the user friendly-form of a butterfly. External influences - interventions for improvement of the driver's behaviour should be presented as a shower on a flower and on the butterfly. Improved behaviour should increase the level of traffic safety.

\section{METHOD}

To achieve the goal - the development of a conceptual model formal procedure has to be followed. Following the procedure insures the identification of the human role in the occurrence of an accident. The development of the procedure as an output of the model is the final phase of this research and development work. It should be implemented in the form of the modified risk assessment model in the real situation. The risk assessment analytical method of work analyses from $\mathrm{AH}$ model [2] has been improved with root cause analysis [12] of behavioural patterns and analysis of human functions [14]. All these methods have to be integrated in the final procedure which should be incorporated in the proposed Butterfly Flower Shower Model (BFS Model) of human behaviour. The procedure, as it is developed and presented, should be used in the real situation. The basis of the proposed conceptual BFS Model is the butterfly model [3] improved with impacts of the environment described as shower and flower and precise description of human behaviour pattern elements.

\section{RESULTS}

The results of this research and the development work are presented as a conceptual BFS Model, and all steps obligatory for its implementation are described. There are four main steps of BFS Model implementation. For each of the four steps the main content of the step with the concept of the procedure is described. 


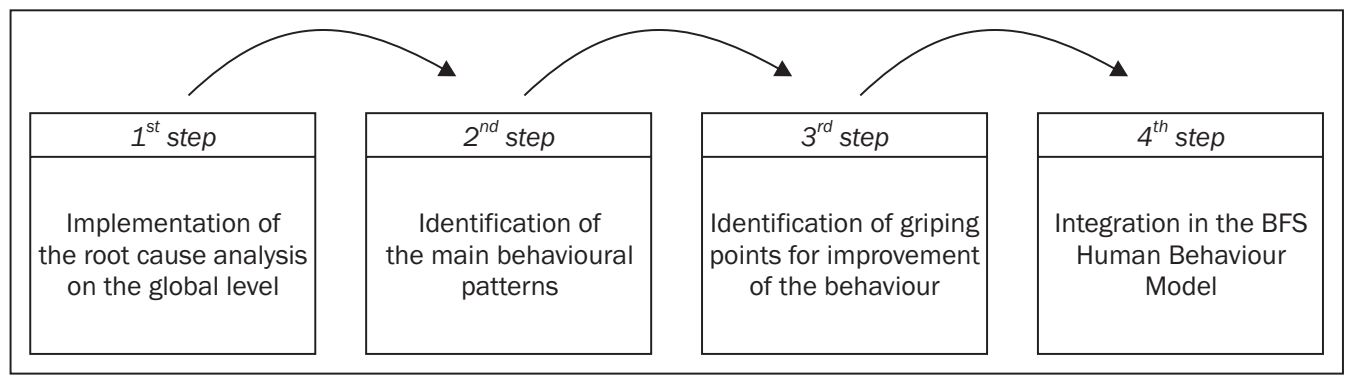

Figure 1 - Four steps of the BFS Human Behaviour Model

Formal presentation of the model's steps is presented in Figure 1.

\subsection{Implementation of the root cause analysis on the global level ( $1^{\text {st }}$ step)}

Implementation is performed according to the $\mathrm{AH}$ model to identify four main root categories of the accident's root cause:

(1) Environmental causes,

(2) Technological causes,

(3) Organizational causes,

(4) Human factor causes.

Accidents as consequence of environmental causes, technological causes and organizational causes are not taken in the further analytical procedure. Only accidents with human factor causes are included in the second step of the proposed analytical procedure.

\subsection{Identification of main behavioural patterns $\left(2^{\text {nd }}\right.$ step $)$}

For accidents with identified human factor causes, the main behavioural patterns have to be identified in the analysed event's situation. For the main behavioural pattern the root cause of the event together with the identification of the human root cause is performed.

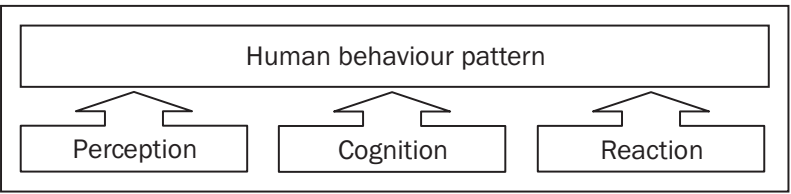

Figure 2 - Possible root causes of inadequate behavioural pattern

The main root causes should be in perception, or in cognition, or in reaction, according to the main proposition of the presented work. The proposed approach is limited to the perception, the cognition, and the reaction of an individual - of the driver. Limitations and disturbances on perception, cognition, and reaction are possible root causes of the event. Special individual conditions like stress [13], anxiety, unfitness for duty, should influence the perception, cognition, and reaction of the driver. Identification of these influences demands further analysis.

\subsubsection{Limitations and disturbances of the perception}

Perception is individual ability to perceive the information [14]. In the majority of working situations, and especially in the traffic situation, the most relevant perception channels are seeing and hearing. The speed of perception ability is measured in milliseconds. The measurable dimension is the ability to distinguish the information (visual or auditive) from the background. Limitations on the human perception side could be caused by illness, age, damages, fatigue or unfitness of the individual. Disturbances and limitations in the perception on the human side are:

- Disturbances in the distinction between different stimuli.

- This is the disturbance, when there are different stimuli, but the individual does not distinguish between them. They are all the same for the individual in the situation.

- Oversight of the stimulus.

- The stimulus is there but the individual does not perceive it. Oversight could be the consequence of the same perception limits as limitations in the distinction between different stimuli. The external consequence is not the same one. The output of the situation is oversight of the stimulus, which is present.

- Stereotype fixation on the stimulus.

- The external manifestation of this limitation is human focusing on one stimulus without the possibility to see, to perceive the new one, or the other one. Causes of this limitation could be also previous experiences of the driver beside limitations caused by human unfitness.

- Shortcut due to similar associations.

- The shortcut is manifested in the perseverance on one stimulus on the basis of its similarity with the other one. There are semantic similarities but not similarities in exterior between stimuli. The basis for this limitation should be 
also in personality traits of the individual in the situation.

\subsubsection{Limitations of the cognition}

Cognition is a common word used for description of the process going on in the individual brains. There are two entities of this process: the adaptation and the accommodation [14]. The individual has to adapt to the situation presented with information from the situation. On the other side they have to adapt the situation to them. In the traffic situation it is more often that the individual traffic infrastructure user has to adapt their behaviour to the situation on the road and to the traffic. The perceived information has to be accepted, processed, validated and incorporated in the process of decision making. The most frequent limitations in the process of cognition are:

- Not accepted information.

- The stimulus is perceived, but its information is not accepted due to limited understanding of it. The individual is not able to understand the information due to the limited knowledge of the situation. Basis for this limitation are poor competences of the individual, personality structure and health status of the traffic user.

- Incorrect interpretation.

- The information is accepted but it is not adequately interpreted. This limitation is the consequence of limited competence due to inadequate knowledge and skills. The root cause of this limitation is inadequate training of the driver for possible situations.

Limitations in acceptance and interpretation of the information shape process of adaptation and accommodation. The processes of adaptation and accommodation are joint processes. They form the chain of cognition process. On the basis of understanding of the information the individual adapts to the situation or tries to accommodate the situation to them.

Limitations of the cognition should be shaped with the driver's unfitness due to the consumption of psychoactive substances, with driver's stress, anxiety, and low or inadequate motivation. Identification of these influences on cognition process demands further analysis.

\subsubsection{Limitations of the reaction}

Reaction is the individual ability to perform the action in accordance with the perceived and processed information. The term reaction describes performance of the action in accordance with circumstances. Reaction abilities of an individual depend on their motor abilities, age and psychophysical condition. On the basis of perceived and evaluated information adequate decision is performed. The external manifestation of this decision is reaction. The most frequent limitations in human reaction are variability and poor coordination.

- Variability of reaction

- The performed reaction is not precisely the same in the same external situation. It is only an approximation of adequate reaction. Not precisely performed reaction pattern could cause an error. Higher probability for variable reaction is when traffic users have not enough skills for the situation. Very skilled traffic users have less probability for unpredicted variable behaviour in the traffic situation; their reactions are always almost the same.

- Poor coordination of reaction.

- Poor coordination is manifested as not precisely performed reaction. There are not coordinated actions between human legs and arms. It is frequent cause of an error for older drivers with health problems. It is presented also in unskilled drivers or traffic users under the influence of psychoactive substances [8]. The influence of psychoactive substances on the traffic user is manifested in poor and slow reaction. Poor coordination of reaction is the most frequent externalization of drug influence on the traffic user [14].

On the basis of perceived evaluated information action is performed. The perception, the processing, the decision making and the reaction are combined in the performed behavioural pattern. This is the external manifestation of all those processes in the individual. The external manifestation is too fast reaction, wrong reaction or too slow reaction. Detailed root cause analyses identify the origin of inadequate behavioural pattern.

\subsubsection{Human behaviour patterns}

According to the complexity of decision-making process in the individual, there are three levels of behaviour complexity: skill-based, rule-based, and knowledge-based behaviour [15].

- Skill-based behaviour.

- The lowest level of behavioural complexity is the most frequent behaviour pattern. Processes of accommodation and adaptation are very fast, often without conscious control. This decisionmaking process is not time-consuming and it is very convenient for the situation with limited available time. In the reality, in the traffic situation, there is no time for time-consuming decision making. The available time in traffic situation permits only effective rudimental decision-making process. External manifestation of this process is skill-based behaviour. 
- Rule-based behaviour.

- The behaviour on the second level, rule-based behaviour, is the second most frequent behavioural pattern. Rule-based behaviour is more complex. It requires knowledge of important information and performance of behavioural patterns adequate to the situation. Processes of adaptation and of the accommodation strictly follow the rules for behaviour in the situation. The process is not as fast as skill-based behaviour due to the longer procedure. The decision-making process based on the rule-based behavioural patterns is more time-consuming, but it is very precise and most adapted to the situation. This process is the best one. External manifestation of rule-based behavioural pattern is behaviour strictly following procedures.

- Knowledge-based behaviour.

- Behaviour on the third level, knowledge-based behaviour, is less frequent behaviour pattern. In reality there is no time for time-consuming behaviour in traffic situation. In the traffic situation, the whole process, from perception via cognition to reaction, has to be fast due to the limited available time. Traffic situations permitting knowledge-based behaviour are extremely rare. Some unpredicted traffic situations demand knowledge-based behaviour. The external manifestation of this behaviour is original behaviour pattern specific for each traffic user.

Three levels of behavioural patterns are external manifestations of decision-making process in each situation, including the traffic situation.

In the process of root cause analysis detailed identification of particular behavioural pattern elements has to be performed. There are three groups of these elements:

- Perception,

- Cognition,

- Reaction.

Identified element with their values (0/1 scale) could be incorporated in the model describing the accidental situation.

\subsection{Identification of gripping points for improvement of human behaviour ( $3^{\text {rd }}$ step)}

Identified gripping points for intervention should ensure improvement of the human behaviour. On the basis of identified causes of an occurred error, suggestions for human behaviour improvement are possible. The final goal of all implemented procedures is to avoid inadequate behaviour and to reduce possible errors to the minimum. The gripping points for interventions are identified possible limitations in perception, cognition and reaction. Possible interventions are focused on improvements of perception, cognition, and reaction.

\subsubsection{Improvements of perception abilities}

There are average values of visual perception abilities and average values for additive perception abilities, which have to be considered in the design of traffic infrastructure. The distribution of perception ability in the population is in accordance with the normal curve. In the design of the traffic infrastructure (i.e. tunnels, signs and all warnings) the perception abilities below the population mean interval have to be taken into account as the limiting values. Visible distinct information has to be placed in the traffic in-

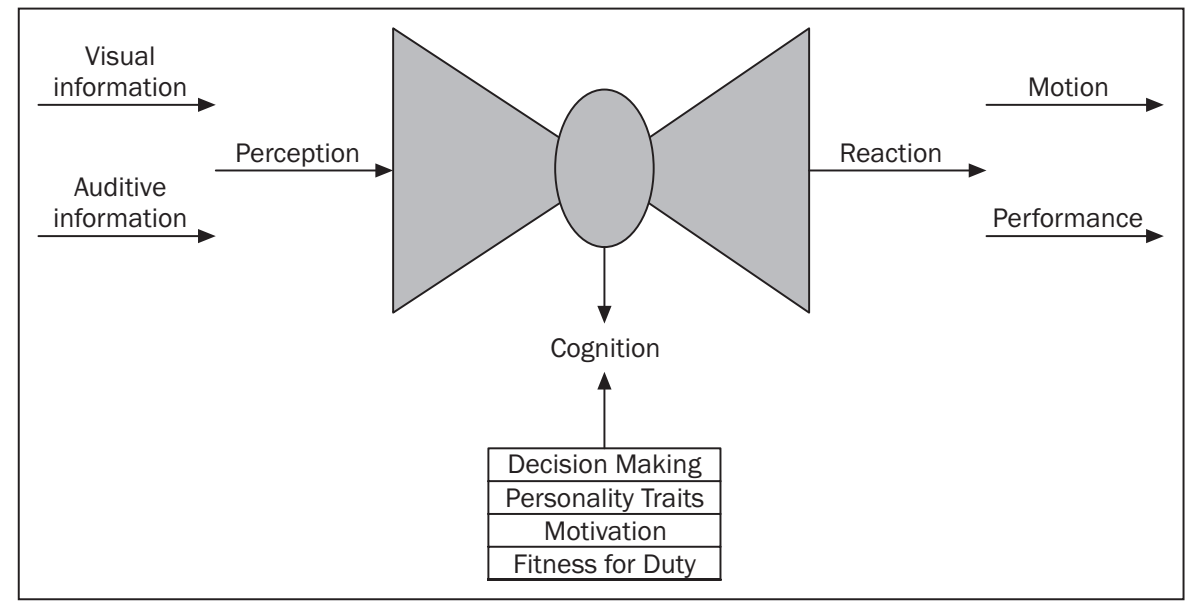

Figure 3 - The basic Butterfly model of behavioural patterns includes all elements of driver's behavioural pattern. The input in the butterfly model is Perception and the output is Reaction. In the body of this model are (1) cognition, with (2) decision making, influenced by (3) personality traits, (4) motivation, and (5) fitness for duty. On the left wing of the butterfly, there is perception of information. On the right wing of the butterfly there is reaction in the form of motion. 
frastructure. Visible information can be perceived by people with perception abilities on the lower limit of population average. Important suggestions to designers of traffic infrastructure are:

- Characters that are big enough to be perceived as information unit (i.e. not too big);

- Characters that are distinct from the background (i.e. shapes and colours);

- Not too many information in one place;

- Use of colours in accordance with semantic meanings (i.e. green - no problems, red - danger, yellow and black - important messages).

Investments in traffic infrastructure to ensure better and easier perception also for traffic users with limited perception abilities is the best solution and the only one due to the aging of population.

There are also medical checks to evaluate driver's individual perception abilities. These verifications are not enough. The content of medical checking differs between different countries. Improvements in the traffic infrastructure are the same for all traffic users. They are more general, not depending on the particular country. These improvements ensure also perception in adverse whether conditions, also when the driver is tired or ill.

\subsubsection{Improvements of cognition}

In the traffic situation there is no time for timeconsuming decision making. Situations permitting knowledge-based behaviour are rare. Usually, there is only enough time for the skill-based behavioural patterns performance. Due to this fact only rudimental decision-making processes are possible. Information has to be presented in a way that assures possibility to perceive them in limited time and to process them on the skill-based level in limited time.

In stress situations (i.e. fire, explosion, accident) [16], the individual is less able to process information and to take into account all circumstances and background information. Important suggestions to driver's training are:

- Investments in the training of drivers are obligatory.

- The goal of the training has to be: "achieving of driving skills via rule-based behavioural patterns to skill-based behavioural patterns".

- Refreshment training of traffic infrastructure users should be strongly recommended.

- Training of drivers for accidental situations.

\subsubsection{Improvement of reaction}

The important suggestion that has to be taken into account is the necessary time to perform the reaction from perception of information, via cognition to the reaction. This time has to be incorporated in the design of traffic infrastructure and in the training process of drivers.

In the performance of reaction there are errors due to the influence of stress. The consequence is uncoordinated, confused, imprecise reaction of the driver. If the driver is older or ill, those reactions could be even slower and more confused [22].

In the traffic situation there is also the speed of travelling that has to be considered. In the design of traffic infrastructure the reaction time is transformed into the distance.

The important suggestions to designers of traffic infrastructure and to driver's trainers are:

- The distance of reaction time and the distance of travelling have to be combined in a unique distance needed between information and accident, exit or reaction that has to be performed.

- On the driver's side improvements are possible in the training procedure. Achieving of behaviour at the professional skill level is the final goal. Precisely performed behavioural pattern on the skill-based level is the best prevention of error occurrence and it is not time consuming.

All possible interventions are focused on the driver and on the traffic infrastructure. They form the shower watering the butterfly and the flower where the butterfly is sitting. The driver is presented in the form of a butterfly. The flower presents the traffic infrastructure. The traffic infrastructure is the road with all signs and warnings. The special traffic infrastructure is a tunnel. To form the emotional aspect the tunnel presents the entire underground. According to the results from occupational health research the work underground is more stressful [18].

\subsection{Integration in the BFS Human Behaviour Model ( $4^{\text {th }}$ step)}

Primary view - Identification of model's elements:

1. Road

1.1. Tunnel

1.2. Crossing

1.3. Bridge

1.4. Highway

1.5. Local road

2. Signs and warnings

2.1. Speed limits

2.2. Directions

3. Driver

3.1. Perception

3.2. Cognition

3.3. Reaction

4. Interventions

4.1. Modification of traffic infrastructure

4.2. Driver selection

4.3. Driver training 


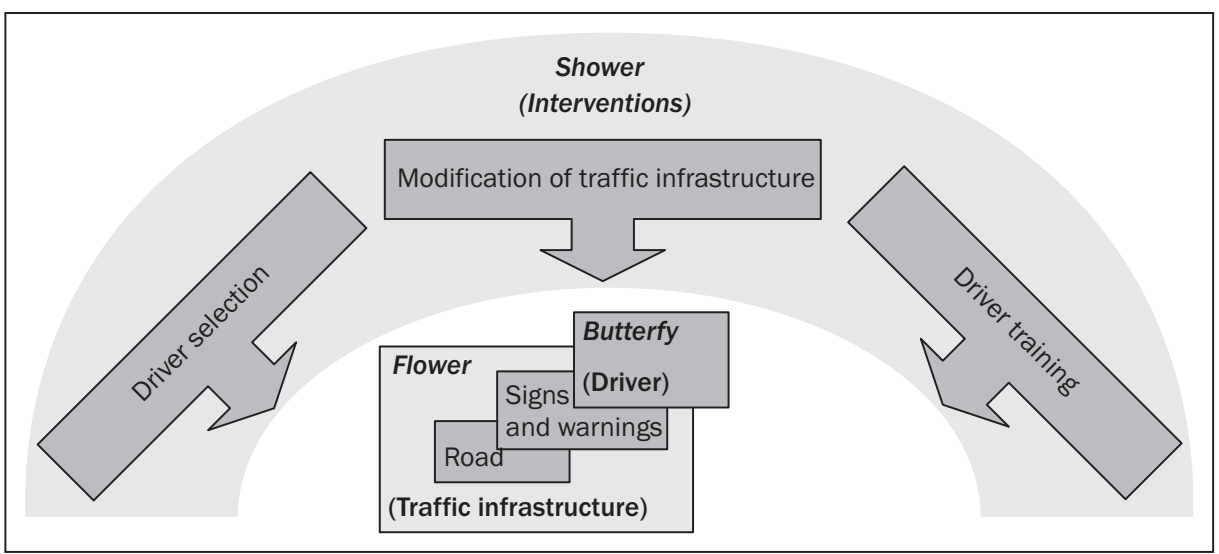

Figure 4 - BFS Human Behaviour Model

Secondary view on the BFS model - Creation of user-friendly presentation:

1) Butterfly (Traffic User)

- Driver - wings (perception and reaction) and body (cognition)

2) Flower (Traffic Infrastructure)

- Road

- Signs and warnings

3) Shower (Impact on Flower and Butterfly)

- Interventions - types of raindrops

Identification of root cause of the accidents and identifications of main behaviour patterns are the first and the second steps of proposed analytical procedure. Identification of possible gripping points for intervention and interventions in the traffic infrastructure or into the driver are the second and the third step of proposed procedure. All four steps have to be integrated in the proposed BFS Human Behaviour Model.

The model describes human behaviour and possible impacts of interventions into the traffic infrastructure and into the driver's behaviour. The model presents the driver-traffic relation. The butterfly represents the driver, the flower represents the traffic infrastructure and the shower represents the intervention in the entire traffic situation. Traffic situation is composed of the driver and of the traffic infrastructure. All key elements of the BFS Model are defined during four steps of the procedure. The majority of proposed procedures had been known before and they had been used as part of previous procedures in the design of traffic infrastructure, in the training of drivers and in procedures of medical evaluation. The novelty is the integration in the unique model describing human behaviour in the traffic situation. The approach offers the possibility of implementation and it is user-friendly externalization of the model. Procedures form the manual of the BFS Model.

\section{CONCLUSION}

The proposition of the work has been realized. The conceptual BFS Model has been developed. All its key elements are defined. The model presents a user-friendly connection between driver, road, and interventions to both of them. They form the traffic. The interventions have to be focused on the driver and on the traffic infrastructure. The main purpose of all interventions is assurance of traffic safety. The proposed BFS Model has an ambition to present relations in the traffic and possible interventions to improve the traffic safety. The proposed model is on the conceptual level and it just formalizes and presents relations in the traffic. Further research work and collection of data from accident analyses should confirm the model or it should demand tailoring of the model to the new reality. The main focus of presented work is on human behaviour and its elements. It has justification from the risk assessments. Risk assessment is the tool for risk reduction. Due to the fact that majority of incidents are consequences of human mistakes, investments in human behaviour improvement are reasonable. Precise determination of behavioural patterns and elements of these patterns are necessary to avoid and to reduce human mistakes. Cutting of behavioural pattern on its elements which should be incorporated in the model is obligatory.

All elements of human behaviour patterns are identified and located in the proposed BFS Human Behaviour Model. The butterfly gets the shower. The shower forms interventions in the perception, in the cognition and in the reaction of the traffic infrastructure user. The flower where the butterfly is sitting is the traffic infrastructure. Interventions have to be done also in the traffic infrastructure. They provide the driver with the possibility to modify behaviour. There are as many flowers in the field as there are roads, bridges or tunnels. There are as many butterflies as there are drivers. All the flowers have some common traits, the same as all 
butterflies have some same characteristics, but each one is a unique one.

For all elements of the BFS Model there are particular procedures describing possible or necessary interventions into the elements of the butterfly or of the flower. The procedures describe the shower elements and determine the paths of interventions. The presentation of a particular procedure is not the aim of this paper.

The identified elements in the model presented in this paper are general. In each particular actual situation the modification is necessary. It should be adapted to the particular situation. All identified limitations in the analysed traffic situation have to be removed or changed. Interventions in those elements removing or minimizing limitations are necessary. In the design process of the new traffic infrastructure taking into account all elements of butterfly sitting on the flower are recommended.

In the design process of the new traffic infrastructure, the main attention has to be paid to the traffic infrastructure. But in the existing reality, for the improvement of the level of traffic safety the great and even greatest attention has to be paid to the centre of the BFS Model - the driver. The driver is getting older and older [17]. The driver is driving ill and tired [19]. The driver has to be aware of their influence on the traffic safety. We have to realize that improvement of traffic safety demands interventions on both of them. The butterfly and the flower are connected. The butterfly is flying from one flower to another, the same as the diver driving on different roads.

Dr. MARIJA MOLAN, univ.dipl.psih.

E-mail: marija@molan.ws

Klinični center Ljubljana

Klinični inštitut za medicino dela, prometa in športa

Poljanski nasip 58, 1000 Ljubljana, Slovenija

Mag. Sc. GREGOR MOLAN, univ.dipl. ing. mat.

E-mail: gregor.molan@comtrade.com

Comtrade d.o.o.

Litijska cesta 51, 1000 Ljubljana, Slovenija

\section{POVZETEK}

\section{MRD - MODEL ČLOVEKOVEGA VEDENJA ZA PROMETNO VARNOST}

Model človekova vedenja Metulj-roža-dež (MRD) opisuje človekovo vedenje $v$ katerikoli zahtevni in nevarni situaciji. Predstavljen je MRD model za uporabo v prometu.

Identificirani so osnovi elementi človekovega vedenja, kar so percepcija, kognitivna obdelava in reakcija. Predstavljene so tudi napake in omejitve po posameznih komponentah človekovega vedenja. Model je predstavljen kot metulj na roži, na katerega dežujejo intervencije. Roža predstavlja prometno infrastrukturo sestavljeno iz okolja, tehnologije in organizacije.

Telo metulja je človekova kognitivna obdelava, na katero vpliva človekova osebnost in motivacija. Levo krilo metulja predstavlja voznikove perceptivne zmožnosti. Desno krilo metulja predstavlja voznikove reakcije. Metulj predstavlja voznika, roža predstavlja cesto s celotno infrastrukturo, dež predstavlja humanizacijske intervencije tako $v$ prometno infrastrukturo kot tudi v voznika. Posamezne kaplje $v$ plohi dežja so povezane z identificiranimi omejitvami v prometni infrastrukturi in pri vozniku. Humanizacijske intervencije so usmerjene $k$ izboljšanju zaznavanja, kognitivne obdelave in reakcijskih zmožnosti voznika tudi na osnovi intervencije $v$ prometno infrastrukturo.

\section{KLUČNE BESEDE}

Metulj-roža-dež, model človekovega vedenja, zaznavanje, kognitivna obdelava, reagiranje, vedenjski vzorci, prometna infrastruktura, promet, voznik, model vedenja, humanizacijski ukrepi

\section{LITERATURE}

[1] Molan M. Deset zapovedi humanizacije dela. Delo in varnost, 1996; 41 (3): 103-105.

[2] Molan M., Molan G. Model povezave razpoložljivosti in delovnega okolja = Model for connection of actual availability and workload. Sanitas et labor, 2001; 2 (1); 27-41.

[3] Molan M., Petelin S., Kožuh M., Molan G. Human factor and evacuations models. V: Hernavs B. (ur), Anžek M. (ur), Janša S. (ur). 13. mednarodni simpozij o elektroniki v prometu, 26. in 27. maj 2005. Inteligentni transportni sistemi - ITS. Ljubljana; Electrotechnical Society of Slovenia, 2005, pp. 1-10.

[4] Molan M., Molan G., Petelin S., Kožuh M. Identification of qualitative and quantitative elements of human behaviour and their inclusion in risk assessment models. ISEP. 2007, 09.05-11.05.2010, Ljubljana.

[5] Sonntag K., Psychological approaches to OSH research-an evaluation of 20 years of psychological research on industrial safety and health in Germany, Int J Occup Saf Ergon. 2001;7(4):561-73.

[6] Deci, Edward L., Intrinsic motivation and self-determination in human behavior / Edward L. Deci and Richard M. Ryan. - New York; London : Plenum, 1985. - XV, 371 str. ; $24 \mathrm{~cm}$. - (Perspectives in social psychology), pp 149-175

[7] James E. Driskell, Eduardo Salas, Stress and human performance, 1996, pp 49-88

[8] Rus - Makovec M., Jakopič J., Driving under alcohol influence and road-traffic safety: to punish or to treat alcohol non-dependent and dependent drivers?, Zdrav Vestn 2010; 79: 582-592

[9] Pew R. W., Mavor A. S., Committee on Human-System Design Support for Changing Technology, National Academies Press, 2007, 135-252

[10] Button K. J., Hensher D. A., Handbook of transport systems and traffic control, Emerald Group Publishing, 2001, 143-175

[11] Nachreiner F., Schultetus W., Standardization in the Field of Mental Stress (DIN EN ISO 10075 Series Standards), Original: DIN-Mitteilungen 81., 2002, 8:519533 
[12] Tyrone S. T., SAl's behavior-based root cause analysis, Human Factors and Power Plants and HPRCT 13th Annual Meeting, IEEE 2007, 288-290

[13] Lazarus, R.S.; \& Folkman, S.: Stress, appraisal, and coping, Springer, New York, 1984.

[14] Lindsay, Peter H., Human Information Processing, Academic Press, inc, 2nd edition, New York, 1977

[15] Embrey, D. (last modification date Oct, $3^{\text {rd }}, 2006$ ). Understanding Human Behaviour and Error. www. humanreliability.com/articles/Understanding\%20 Human\%20Behaviour\%20and\%20Error.pdf

[16] Reid L.D.: A survey of recent driver steering behaviour models suited to accident studies, Accident Analysis \& Prevention, Volume 15, Issue 1, February 1983

[17] Alispahić, S., Antunović, Z., \& Becirović, E.: Training of Drivers in the Function of Road Traffic Safety. Promet Traffic-Traffico, Vol. 19, No. 5, pp. 323-327.
[18] Weyman, A., Clarke, D. D. \& Cox, T. (2003). Developing a factor model of coal miners' attributions on risktaking at work. Work \& Stress, 17(4), 306-320.

[19] Strahan, C.; Watson, B.; \& Lennonb, A.: Can organisational safety climate and occupational stress predict work-related driver fatigue?, Transportation research Part F: Traffic Psychology and Behaviour, Vol. 11, No. 6, 2008, pp. 418-426.

[20] Shinar, D. Traffic Safety and Human Behavior, Elsevier Science Ltd, 2007

[21] Directive 2004/54/EC on minimum safety requirements for tunnels in the Trans-European Road Network, Brussels, 29 April 2004.

[22] Tollazzi, T., Rencelj, M., \& Zalar, B.: Traffic Safety of Older Drivers in Various Types of Road Intersections. Promet Traffic-Traffico, Vol. 22, No. 3, pp. 193-201. 